\title{
Resolution of osseous sarcoidosis with steroids
}

\author{
Kulothungan Gunasekaran, ${ }^{1}$ Mudassar Raees Ahmad, ${ }^{2}$ Bhavin Dalal, ${ }^{3}$ Lee Edmonds ${ }^{4}$
}

${ }^{1}$ Division of Hospital Medicine, Henry Ford Health System, Detroit, Michigan, USA ${ }^{2}$ Geisinger Health System, Danville, Pennsylvania, USA ${ }^{3}$ Beaumont Health System, Royal Oak, Michigan, USA

${ }^{4}$ Bassett Medical Center, Cooperstown, New York, USA

\section{Correspondence to} Dr Kulothungan Gunasekaran, stankuloth@gmail.com

Accepted 25 February 2018

\section{DESCRIPTION}

A 56-year-old man with a 10-pack-year history of smoking presented to the clinic with left hip pain. He was treated symptomatically with pain medications. With persistence of symptoms and normal preliminary laboratory results, he underwent MRI of the pelvis which showed lytic lesions suggestive of metastatic disease (figure 1A). Further imaging including CT of the chest revealed bilateral hilar and mediastinal adenopathy along with splenomegaly but no parenchymal lung involvement. Mediastinoscopy with lymph node biopsy showed non-caseating granuloma, and left pubic area biopsy revealed benign bone with epithelioid granuloma, both consistent with sarcoidosis. His pulmonary function tests revealed normal spirometry, lung volume and diffusion. Without any organ dysfunction, he was started on prednisone $40 \mathrm{mg}$ once daily for his hip pain. After 6 months of steroid use, he had significant clinical and radiological improvement (figure 1B). Sarcoidosis is a multisystem disease characterised by the formation of non-caseating granulomas. It occurs classically in lungs and skin but almost any organ can be involved; and bone involvement is also not uncommon. Corticosteroids and/or methotrexate are commonly used in the treatment and usually control symptoms, but radiographs may not show any improvement. ${ }^{1}$ Two previously reported cases

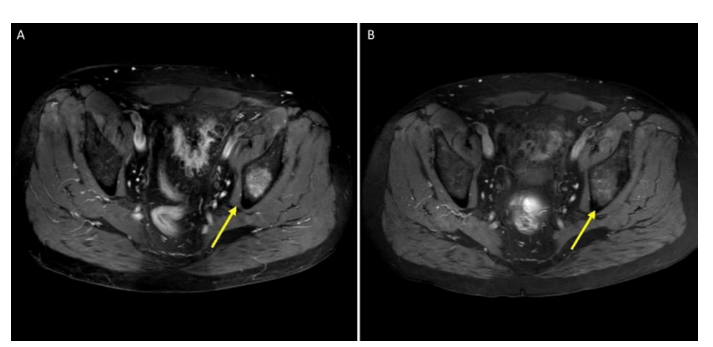

To cite: Gunasekaran K Ahmad MR, Dalal B, et al. BMJ Case Rep Published Online First: [please include Day Month Year]. doi:10.1136/bcr-2017224064

Figure 1 (A) MRI axial view showing enhancing lesion in the left acetabulum. (Yellow arrow)(B) MRI axial view showing resolution of the skeletal lesion after 6 months on prednisone(Yellow arrow).

\section{Learning points}

- Osseous sarcoidosis can cause cystic, reticular or destructive lesions of the bone.

- MRI is the most sensitive imaging modality to detect active granulomas in bone, joints and muscles.

- Antigranulomatous therapy including glucocorticoid and/or methotrexate is the commonly used treatment, and follow-up imaging may show radiographic improvement.

showed resolution of sarcoid hand bone lesions after treatment with methotrexate and prednisone. $^{2} 3$ Our case was interesting because of the lack of parenchymal lung involvement and near-complete resolution of bony abnormalities on MRI with the use of steroids alone, which is rarely reported.

Contributors $K G$, the primary author, was responsible for data acquisition, analysis, interpretation and manuscript preparation. MRA participated in manuscript preparation and edition. BD participated in data interpretation and manuscript evaluation. LE supervised the development of the manuscript and final evaluation. All authors read and approved the final version of the manuscript.

Funding The authors have not declared a specific grant for this research from any funding agency in the public, commercial or not-for-profit sectors.

Competing interests None declared.

Patient consent Obtained.

Provenance and peer review Not commissioned; externally peer reviewed.

(C) BMJ Publishing Group Ltd (unless otherwise stated in the text of the article) 2018. All rights reserved. No commercial use is permitted unless otherwise expressly granted.

\section{REFERENCES}

1 Chatham W. Rheumatic manifestations of systemic disease: sarcoidosis. Curr Opin Rheumatol 2010;22:85-90.

2 Ahmanna-Chakir F, Becce F, Aubry-Rozier B. Osseous Sarcoidosis Revealed by a Pathologic Fracture and Successfully Treated With Methotrexate and Prednisone. Arthritis Rheumatol 2016;68:472

3 Gardner GC, Hunter JC. Clinical images: Radiographic healing of osseous sarcoidosis. Arthritis Rheum 2005;52:2225. 
Copyright 2018 BMJ Publishing Group. All rights reserved. For permission to reuse any of this content visit http://group.bmj.com/group/rights-licensing/permissions.

BMJ Case Report Fellows may re-use this article for personal use and teaching without any further permission.

Become a Fellow of BMJ Case Reports today and you can:

- Submit as many cases as you like

- Enjoy fast sympathetic peer review and rapid publication of accepted articles

Access all the published articles

- Re-use any of the published material for personal use and teaching without further permission

For information on Institutional Fellowships contact consortiasales@bmjgroup.com

Visit casereports.bmj.com for more articles like this and to become a Fellow 